\title{
Analisis Kesiapan Pemerintah Provinsi Kalimantan Tengah dalam Wacana Pemindahan Ibu Kota Negara Republik Indonesia ke Kota Palangkaraya
}

\author{
Nicodemus R Toun \\ nicotoun@gmail.com
}

\author{
Dosen Magister Administrasi Publik \\ Universitas Muhammadiyah Palangkaraya
}

\begin{abstract}
Abstrak
Artikel ini merupakan hasil studi lapangan yang terkait dengan wacana pemindahan Ibu Kota Republik Indonesia dari Jakarta ke Palangkaraya. Secara umum, pemerintah daerah Kalimantan Tengah menyatakan kesiapan dan persetujuan terkait wacana yang digulirkan oleh pemerintah pusat tersebut, namun gubernur Provinsi Kalteng mengingatkan ada beberapa hal yang perlu untuk diperhatikan jika wacana tersebut benar-benar akan diwujudkan. Beberapa persoalan pokok tersebut adalah kesiapan anggaran untuk pembangunan infrastruktur, perencanaan tata ruang wilayah yang baik, perencanaan kesiapan SDM, dan aspek-aspek sosial budaya yang perlu untuk menjadi perhatian. Studi ini dilakukan dengan wawancara mendalam terhadap beberapa informan serta analisis dokumentatif baik yang bersumber dari surat kabar, pemberitaan-pemberitaan di radio maupun di televisi dan studi lapangan oleh peneliti. Studi ini menyimpulkan bahwa, meskipun pemerintah daerah Kalteng sudah menyatakan kesiapannya, namun banyak faktor yang perlu untuk diperhatikan, terutama aspek sosial, politik, birokrasi, dan daya dukung lingkungan hidup. Peneliti menyimpulkan bahwa perlu dilakukan kajian mendalam terkait dengan perencanaan tersebut agar tidak menimbulkan permasalahan di kemudian hari.
\end{abstract}

Kata Kunci: Ibu Kota Negara, Wacana Pemindahan Ibu Kota, Pemda Kalteng

\section{Latar Belakang}

Wacana pemindahan ibu kota negara sudah cukup lama, bahkan sejak era pemerintahan Presiden Sukarno wilayah Kalimantan sudah dipandang sebagai kawasan ideal bagi penempatan wilayah ibu kota baru untuk menggantikan Jakarta. Selain wilayah yang luas, aman dari potensi gempa 
bumi, juga dianggap sebagai kawasan pertengahan Indonesia. Beberapa negara yang pernah melakukan pemindahan ibu Kota adalah Korea Selatan yang memindahkan pusat ibu kota dari seoul ke Senjong, Malaysia dari Kuala Lumpur ke Putrajaya, Amerika Serikat yang memindahkan pusat pemerintahan ke Washington dengan tetap menjadikan New York sebagai pusat perekonomian dan bisnis, Brazil yang memindahkan ibu kota dari Rio de Janeiro ke Brasilia serta Turki yang memindahkan ibu kotanya dari Istanbul ke Ankara. Dan dari sekian banyak pengalaman pemindahan ibu kota tersebut menjadi catatan khusus dari Bappenas RI, seperti pemindahan ibu kota Australia ke Canberra yang tidak menimbulkan efek perkembangan wilayah yang berarti, serta pemindahan ibu kota Malaysia ke Putrajaya yang jaraknya terlalu dekat sehingga dampak positif dari pemindahan ibu kota tersebut tidak signifikan untuk menyelesaikan berbagai permasalahan dari ibu kota sebelumnya.

Sonny Harry B Harmadi (2018/10/1-Tribunnews.com) mengungkapkan bahwa menyebutkan bahwa ada enam syarat dari pertimbangan dalam menentukan wilayah ibu kota baru. Syarat-syarat tersebut adalah:

1. Wilayah tersebut memiliki jaringan yang baik dan terhubung dengan pusat aktivitas politik.

2. Kepadatan penduduk yang rendah.

3. Resiko bencana yang rendah.

4. Daya dukung lingkungan yang baik.

5. Aman dalam perspektif pertahanan dan ketahanan nasional.

6. Memiliki potensi dikembangkan sebagai kawasan pertumbuhan ekonomi baru.

Menteri Perencanaan Pembangunan Nasional atau Kepala Bappenas Bambang Brodjonegoro menyatakan bahwa wacana pemindahan ibu kota negara telah dibahas bersama presiden Republik Indonesia Joko Widodo di istana negara. Hal ini menunjukan bahwa mulai ada upaya serius dari pihak 
pemerintah pusat untuk melakukan kajian terhadap proses pemindahan ibu kota negara mengingat daya dukung sosial dan lingkungan di Kota Jakarta saat ini sudah dianggap tidak layak.

Palangkaraya dianggap sebagai opsi yang terus mengemuka mengingat aspek historis, dimana presiden pertama Ir. Soekarno jauh-jauh hari sudah mewacanakan untuk menjadikan wilayah Kalimantan sebagai modal dan model dari pembangunan Indonesia di masa yang akan datang. Selain itu, luas lahan yang tersedia dianggap cukup luas untuk membangun infrastruktur yang diperlukan untuk keberadaan sebuah ibu kota negara. Meski demikian ada beberapa hal yang menjadikan wacana ini menjadi pro dan kontra, gubernur Kalimantan Tengah mengakui bahwa ada beberapa kekhawatiran dari beberapa tokoh masyarakat tentang wacana tersebut, terutama dampak perubahan sosiologis dari masyarakat Kalimantan Tengah yang hidup dalam karakteristik masyarakat rural-urban atau sub-urban menjadi masyarakat ibu kota yang hidup dalam corak masyarakat metropolitan. Adanya kekhawatiran terkait potensi terpinggirnya masyarakat lokal tersebut menuntut adanya perencanaan yang serius dari pemerintah pusat untuk menghindari dampak sosial jika wacana pemindahan ibu kota tersebut benar-benar terwujud.

Meski isu dan wacana pemindahan ibu kota tersebut telah mengemuka, namun pemerintah provinsi Kalimantan tengah mengaku belum ada rapat serius terkait rencana tersebut. Gubernur Kalimantan Tengah Sugianto Sabran mengaku baru mendapat kunjungan dari Kepala Bappenas yang menanyakan banyak hal terkait dengan Kota Palangkaraya dan sekitarnya, dan belum secara serius membahas tentang hal-hal teknis terkait langkah-langkah realisasi Kota Palangkaraya menjadi ibu kora negara. Gubernur Kalimantan Tengah memaparkan bahwa ada tiga wilayah kabupaten yang direncanakan untuk menjadi wilayah calon ibu kota RI tersebut yakni Kota Palangkaraya, Kabupaten Katingan dan Kabupaten Gunung Mas. Lebih lanjut ia juga memaparkan bahwa wilayah provinsi Kalimantan Tengah memiliki wilayah 
laut, sehingga hal-hal yang terkait dengan mobilitas lewat jalur laut jika nanti rencana tersebut terealisasi tidak menjadi permasalahan yang menghambat rencana tersebut.

Berdasarkan berbagai hal yang telah dipaparkan tersebut, maka penulis akan memfokuskan kajian ini pada aspek-aspek yang menjadi faktor-faktor pendukung ataupun faktor-faktor yang menjadi penghambat dari wacana pemerintah pusat untuk mencari alternatif bagi pemindahan ibu kota negara. Kesimpulan dari kelebihan dan kekurangan wacana pemindahan ibu kota negara dari Jakarta ke Palangkaraya ini akan menggambarkan secara komprehensif kesiapan wilayah Provinsi Kalteng sebagai alternatif utama ibu kota RI pengganti Jakarta.

\section{Kesiapan Lahan Pemukiman dan Tata Ruang Wilayah Kota}

Menurut Kostof (1991) Kota adalah leburan dari bangunan dan penduduk, sedangkan bentuk kota pada awalnya adalah netral tetapi kemudian berubah sampai hal ini dipengaruhi oleh budaya tertentu. UU RI No 4 Tahun 1992 menyebutkan bahwa lahan permukiman adalah bagian dari lingkungan hidup yang berada di luar kawasan hutan lindung. Kawasan-kawasan tersebut dapat berupa kawasan perkotaan maupun kawasan pedesaan. Permukiman berfungsi sebagai lingkungan tempat tinggal atau hunian dan tempat kegiatan pendukung perikehidupan dan sumber kehidupan.

Menurut UU No. 26 Tahun 2007 tentang penantaan ruang, yang dimaksud dengan ruang adalah wadah yang meliputi ruang darat, ruang laut dan ruang udara, termasuk ruang di dalam bumi sebagai satu kesatuan wilayah, tempat manusia dan mahluk lain hidup, melakukan kegiatan dan memelihara kelangsungan hidupnya. Selanjutnya sesuai Kepmen-Kimpraswil No. 327/KPTS/2002 tentang penetapan enam pedoman dalam melakukan penataan ruang, yang dimaksud dengan ruang adalah wadah yang meliputi daratan, ruang lautan dan ruang udara sebagai satu kesatuan wilayah tempat manusia 
dan mahluk hidup lainnya dan melakukan serta memelihara kelangsungan hidupnya.

Wilayah Kalteng memiliki karakteristik seperti dimaksudkan dalam berbagai produk kebijakan tersebut, yakni wilayah daratan yang luas dan sebagian besar masih berupa hutan, wilayah perairan yang terdiri dari wilayah sungai dan laut serta wilayah udara di atasnya. Sebagai sebuah kesatuan wilayah, langkah pertama dalam penataan ruang dan wilayah adalah melakukan analisis dan identifikasi terhadap berbagai karakteristik dari ruang dan wilayah tersebut. Hal tersebut untuk menjamin sebuah kawasan yang arah pembangunannya tetap berorientasi lingkungan, penataan yang konstruktif dan terencana hingga analisis perkembangan wilayah untuk jangka panjang.

Pendapat tersebut menyiratkan bahwa ketika sebuah kawasan baik itu hutan atau non hutan kemudian berubah menjadi kawasan pemukiman, maka wilayah tersebut akan didominasi oleh bangunan-bangunan dan tempat bermukim manusia dalam skala besar jika alih fungsi lahan tersebut membentuk sebuah kawasan perkotaan. Wacana pembentukan kawasan ibu kota negara secara otomatis akan membentuk pola tata ruang yang menjadikan kawasan pemukiman dan perkantoran dalam ukuran yang luas. Hal tersebut untuk mengakomodir fasilitas pemerintahan seperti kawasan perkantoran, kawasan pemukiman bagi para pegawai, kawasan perekonomian, kawasan industri, kawasan olahraga dan hijau serta fasilitas-fasilitas lainnya.

Kalimantan Tengah sebagai sebuah wilayah provinsi yang memiliki wilayah yang luas serta penduduk yang relatif masih sedikit memiliki kriteria baik sebagai wilayah yang mampu menyediakan lahan tersebut. Hanya saja tidak semua kawasan tersebut merupakan wilayah kosong. Di banyak tempat, kawasan-kawasan calon wilayah pusat ibu kota merupakan kawasan pemukiman penduduk, hutan lindung, perkebunan, lahan gambut dan kawasan pendukung bagi daerah-daerah aliran sungai. 
Jika dilihat dari paparan gubernur Kalteng tentang wilayah yang akan dijadikan sebagai kawasan ibu kota, maka wilayah Kabupaten Gunung Mas dan Katingan yang cukup ideal sebagai wilayah pengembangan kota. Hal tersebut karena Kota Palangkaraya sendiri sudah mengalami banyak masalah ekologis dan sosial. Disamping itu, kawasan Kota Palangkaraya sudah dipenuhi oleh bangunan, baik pusat pemerintahan provinsi, pemukiman industri dan lain sebagainya. Ini merupakan tantangan bagi pemerintah dan lembaga yang akan membuat rancangan tata ruang wilayah agar menjadi proporsional dengan mempertimbangkan juga prediksi-prediksi perkembangan wilayah kota dalam jangka panjang.

Kalimantan Tengah merupakan salah satu wilayah provinsi di Indonesia yang memiliki wilayah yang cukup luas. Provinsi dengan ibu kota di Palangkaraya ini memiliki luas $157.983 \mathrm{~km}^{2}$. Secara umum wilayah ini memiliki topografi datar dengan banyak sungai yang mengalir dari wilayah pedalaman hingga ke muara laut Jawa yang mampu menjamin ketersediaan pasokan air dan mendukung banyak program pemanfaatan lahan untuk keperluan pertanian dan lain sebagainya. Dengan kepadatan sekitar 17jiwa/ $/ \mathrm{Km}^{2}$ wilayah provinsi Kalimantan Tengah cukup ideal untuk dibangun menjadi wilayah administratif baru wilayah perkotaan sebagai konsekuensi dari perubahan status sebagai ibu kota negara jika wacana pemindahan ibu kota terealisasi.

Dari paparan yang dilakukan oleh gubernur Kalimantan Tengah telah tergambarkan bahwa tidak ada persoalan terkait dengan ketersediaan lahan dan pembuatan tata ruang baru di wilayah Kalteng seiring dengan rencana pemindahan ibu kota tersebut. Hanya ada beberapa asumsi ekosistem yang menyebutkan bahwa kondisi wilayah Kalteng yang kurang cocok karena karakteristik tanahnya yang berupa gambut sehingga kualitas air yang dihasilkan dikhawatirkan tidak layak untuk dikonsumsi, ataupun potensi banjir yang akhir-akhir ini seringkali melanda wilayah kota Palangkaraya akibat 
rusaknya hutan dan lahan yang cukup luas di wilayah perhuluan Kalimantan Tengah.

Terlepas dari itu semua, wilayah provinsi Kalteng yang luas dan datar merupakan aspek pendukung karena tidak akan menyulitkan pemerintah dalam penyediaan lahan karena kondisi penduduk yang masih relatif jarang dan tersedianya lahan-lahan kosong di sekitar kota Palangkaraya. Ini barangkali yang menjadi pertimbangan pemerintah pusat dalam menjadikan Kalteng sebagai wilayah alternatif yang potensial menjadi kawasan ibu kota negara. Selain itu, ketertinggalan pembangunan di wilayah Kalimantan merupakan pertimbangan lain, dimana dengan ditetapkannya wilayah Kalteng sebagai calon ibu kota provinsi maka diharapkan percepatan pembangunan akan menjadi merata. Hal tersebut karena pembangunan infrastruktur besar-besaran serta besaran dana yang dianggarkan pemerintah pusat menjadi faktor pendorong pertumbuhan kemajuan wilayah Kalteng.

\section{Kesiapan SDM Pendukung}

Sumber daya manusia (human resources) adalah usaha kerja atau jasa yang dapat diberikan dalam proses produksi yang kemudian dapat mencerminkan kualitas hasil usaha yang diberikan oleh seseorang dalam waktu tertentu, kemudian SDM juga dapat diartikan sebagai kemampuan kerja manusia dalam usaha kerja tersebut. Mampu bekerja berarti mampu melakukan kegitan yang memiliki nilai ekonomis yakni kemampuan untuk menghasilkan sesuatu yang dibutuhkan oleh masyarakat, (Sonny sumarsono, 2003:4). Sedangkan Hasibuan, (2003: 244) menyatakan bahwa sumber daya manusia adalah kemampuan terpadu dari daya pikir dan daya fisik yang dimiliki oleh individu. Pelaku dan sifatnya dilakukan oleh keturunan dan lingkungannya, sedangkan prestasi kerjanya dimotivasi oleh keinginan untuk memenuhi kepuasannya. 
Berdasarkan pendapat tersebut, sumber daya manusia merupakan faktor vital dalam kemajuan sebuah daerah karena potensi dan kemampuan setiap manusia yang ada di dalamnya akan menentukan berhasil atau tidaknya berbagai program pembangunan yang ada. Sebagai sebuah wilayah yang diwacanakan sebagai wilayah ibu kota negara, faktor sumber daya manusia merupakan aspek yang perlu dipersiapkan dengan baik oleh pemerintah daerah Kalteng, baik secara kualitas maupun kuantitasnya. Seiring dengan perubahan status menjadi ibu kota negara, maka ada banyak bidang yang membutuhkan ketersediaan sumber daya manusia terampil, baik dalam bidang pemerintahan, politik, ekonomi, sosial, budaya dan pertahanan dan keamanan.

Provinsi Kalteng memiliki beberapa perguruan tinggi negeri dan swasta yang terus mengembangkan berbagai bidang keilmuan meskipun belum maksimal baik secara kualitas maupun kuantitas. Selain itu banyak di antara kader-kader muda Provinsi Kalimantan Tengah yang telah menempuh pendidikan formal di luar daerah, baik di dalam maupun luar negeri. Dengan berbagai kesiapan tersebut maka aspek pendidikan dan potensi sumber daya manusia di wilayah provinsi Kalteng dapat berperan aktif dalam pembangunan daerah dan nasional, serta dapat mendukung wacana pemindahan ibu kota negara dari wilayah Jakarta ke Kota Palangkaraya.

Dari berbagai informasi yang diperoleh dalam studi lapangan, salah satu alasan bagi masyarakat Kalteng yang mendukung wacana pemindahan ibu kota tersebut adalah adanya harapan untuk pelibatan putra putri Kalteng dalam pembangunan dalam skala nasional. Saat ini partisipasi masyarakat Kalteng di tingkat nasional terbilang sangat kecil. Hanya beberapa orang saja yang memiliki kesempatan untuk berkiprah dalam birokrasi pemerintahan pusat. Hal ini terjadi karena sistem rekrutmen yang dianggap kurang terbuka dan kurangnya kesempatan yang diberikan kepada kader-kader daerah Kalteng dalam setiap proses rekrutmen aparatur negara dalam berbagai bidang. 
Masyarakat Kalteng berharap agar hal-hal demikian tidak lagi terulang jika ke depan wilayah Kalimantan Tengah dijadikan sebagai ibu kota negara. Banyak kalangan yang juga khawatir bahwa pemindahan ibu kota negara tersebut akan meminggirkan masyarakat lokal, hal ini tampak dalam penolakan beberapa pihak terhadap rencana tersebut. Pemerintah pusat mesti melakukan komunikasi dan sosialisasi yang intensif kepada masyarakat agar potensipotensi negatif dari wacana pemindahan ibu kota negara ini tidak semakin berkembang dan menghambat upaya pemerataan pembangunan nasional melalui pemindahan pusat ibu kota negara dari Jakarta ke wilayah provinsi Kalimantan tengah.

Beberapa kalangan intelektual yang menjadi informan dalam kajian ini memaparkan bahwa wacana pemindahan ibu kota negara ke Provinsi Kalteng tidak hanya menjadi wacana pemerintah pusat saja. Pemerintah daerah dan masyarakat Kalteng diharapkan dapat dilibatkan secara aktif karena berbagai ekses dari pemindahan ibu kota tersebut akan dirasakan langsung oleh warga Kalteng sendiri. Sejauh ini masyarakat Kalteng baru sebatas menjadi pendengar saja dan bahkan banyak di antara pimpinan daerah yang wilayahnya direncanakan untuk menjadi wilayah pengembangan ibu kota belum diajak bicara. Ini menjadi indikasi yang meragukan bagi beberapa kalangan bahwa rencana pemindahan ibu kota tersebut kurang serius, dan hanya menjadi sebuah program Bappenas yang khawatir terhadap situasi ibu kota Jakarta dengan permasalahan yang semakin kompleks akhir-akhir ini.

Kalangan mahasiswa mengungkapkan bahwa secara umum Kalteng siap untuk berperan aktif dalam penyelenggaraan pemerintahan jika dilibatkan oleh pemerintah pusat. Saat ini sudah banyak lulusan perguruan tinggi yang memiliki kualitas SDM yang cukup diandalkan dalam berbagai bidang. Jika wacana pemindahan ibu kota ke wilayah Kalteng terwujud, maka perkembangan dan kemajuan akan dirasakan oleh masyarakat di berbagai bidang. Kalteng memang masih tertinggal dalam banyak hal seperti 
pembangunan infrastruktur, kesehatan, pendidikan, ekonomi dan bidangbidang lain. Karena itu harapan masyarakat terkait wacanan pemindahan ibu kota negara menjadi sebuah harapan akan perubahan dan kemajuan yang diharapkan oleh seluruh masyarakat. Berkaca dari wilayah Jakarta dan kotakota di sekitarnya, pesatnya pembangunan di wilayah-wilayah sekitar ibu kota disebabkan oleh besarnya konsentrasi penduduk yang menggantungkan kehidupan di wilayah ibu kota.

\section{Dinamika sosial dan Kebudayaan}

Pertumbuhan manusia dari kecil hingga dewasa dan tua merupakan hasil dari bentukan dinamika sosial dan budaya, baik yang ada di sekitar lingkungan kehidupannya maupun dari tempat lain yang memiliki interaksi emosional ataupun sosial melalui perantaraan teknologi atau transfer kebudayaan. Berbagai dinamika tersebut akan mempengeruhi perubahan sikap, tingkah laku, sistem sosial hingga pola kehidupan. Dapat dikatakan bahwa dinamika sosial budaya di sebuah wilayahlah yang membentuk karakter, sikap, dan pandangan-pandangan sosial tertentu oleh masyarakatnya.

Dinamika sosial dan kebudayaan diperkirakan menjadi intensi pokok dalam wacana pemindahan wilayah ibu kota negara ini, dimana banyak pengamat dan kelompok masyarakat di Kalimantan Tengah yang memandang bahwa akan terjadi perubahan besar dalam struktur masyarakat, pola kehidupan serta pola interaksi sosial di wilayah provinsi Kalimantan Tengah. Persepsi tersebut juga akhirnya melahirkan pro dan kontra terkait dengan wacana tersebut. Beberapa pihak memandang bahwa logika dari wacana pemindahan ibu kota negara tersebut adalah sesuatu yang wajar, mengingat daya dukung sosial dan lingkungan di Jakarta yang sudah tidak memungkinkan untuk terus dipertahankan menjadi ibu kota. Sebagian masyarakat memandang bahwa berkaca dari keruwetan Jakarta menjadi ibu kota akan menjadikan Palangkaraya menjadi serupa dengan kehidupan di Jakarta, dimana 
konsekuensi sebagai sebuah kota besar akan memiliki dampak yang besar terhadap kamapanan sosial dan budaya yang ada di Kalteng saat ini.

Beberapa pakar sosiologi telah melakukan pemetaan terhadap perubahan sosial ini yakni:

- Mac Iver; mengungkapkan bahwa perubahan sosial merupakan sebuah fenomena perubahan dalam masyarakat yang terkait dengan hubungan sosial (social relation) dan perubahan dalam keseimbangan sebuah hubungan sosial.

- Gillin; mengemukakan bahwa sebuah perubahan sosial tampak dari variasi-variasi yang hidup di dalam kelompok-kelompok masyarakat yang akhirnya diterima sebagai sebuah kenyataan sosial yang wajar karena adanya perubahan kondisi geografis, komposisi penduduk, kebudayaan, ideology maupun karena adanya proses difusi maupun hal-hal baru yang ditemukan di dalam masyarakat.

- Selo Soemarjan; mengemukakan tentang pengertian perubahan sosial sebagai perubahan dalam lembaga-lembaga kemasyarakatan yang akhirnya akan berpengaruh terhadap sistem sosialnya. Sistem sosial yang dimaksud terkait dengan nilai-nilai, sikap-sikap, dan pola-pola dalam peri kelakuan di antara kelompok-kelompok yang hidup dalam masyarakat.

- Kingsley Davis; mengemukakan bahwa perubahan sosial merupakan perubahan yang terjadi di dalam struktur dan fungsi yang ada di dalam masyarakat.

Berbagai pandangan tersebut merupakan abstraksi dari berbagai pola dalam dinamika perubahan sosial di dalam kelompok-kelompok masyarakat dunia yang banyak di antaranya telah mengalami revolusi sosial maupun kebudayaan. Seiring perkembangan zaman, ada banyak dari nilai-nilai sosial serta struktur masyarakat yang juga ikut berubah. Hal ini tentu akan terjadi juga pada masyarakat di Kalteng setelah terwujudnya wacana pemindahan ibu kota di wilayah tersebut. Dalam analisis penulis, perubahan sosial yang terjadi 
akan sangat besar, dan mencakup hampir seluruh bidang kehidupan masyarakat yang akan berdampak pula pada aspek kebudayaan, geografis, demografis, ekonomi dan banyak lagi persoalan lainnya. Secara sosiologis masyarakat akan mampu untuk beradaptasi dengan berbagai dinamika tersebut, namun namun dalam prosesnya juga perlu dipertimbangkan potensi kejutan budaya maupun konflik di masyarakat terutama konflik sosial dan agrarian.

Interaksi antara berbagai latar belakang, sosial, budaya, agama, asal usul wilayah, latar belakang ekonomi, telah membentuk karakteristik masyarakat Kalteng yang majemuk dan toleran. Hingga saat ini segenap kelompok masyarakat Kalteng menyadari bahwa mereka hidup dalam ruparupa perbedaan yang menjadikan mereka berinteraksi dengan individu-individu atau kelompok yang memiliki latar belakang yang berbeda-beda satu sama lain. Ini merupakan sebuah modal sosial, dimana jika wacana pemindahan ibu kota negara ke wilayah Kalteng, maka wilayah tersebut akan menjadi kota yang plural dan membentuk karakteristik masyarakat yang majemuk karena penduduknya berasal dari berbagai latar belakang suku, agama, latar belakang kebudayaan dan daerah.

Wilayah Provinsi Kalteng merupakan miniatur Indonesia, dimana kemajemukan penduduk menjadi ciri khas demografis di wilayah ini. Hal ini menjadikan provinsi Kalteng menjadi wilayah dimana penduduk dari berbagai latar belakang suku, agama, ras dan golongan hidup harmonis dan toleran. Hal ini menjadi modal sosial yang baik jika ibu kota negara ditempatkan di wilayah Kalteng.

Persoalan sosial dan budaya merupakan aspek penting dalam pembangunan karena akan berpengaruh besar terhadap interaksi sosial masyarakat yang akan semakin bertambah jumlahnya sebagai konsekuensi dari kebijakan pemindahan ibu kota negara tersebut. Penulis menemukan bahwa pedoman hidup yang dianut oleh masyarakat Kalteng sudah sesuai dengan karakteristik bangsa secara umum, dimana pluralisme dan toleransi sudah 
menjadi budaya dan kehidupan sehari-hari. Selain masyarakat asli Kalteng, juga hidup masyarakat yang berasal dari seluruh wilayah Indonesia. Adanya program transmigrasi yang telah digalakkan keberadaannya sejak era orde baru menjadikan banyak kelompok-kelompok pemukiman transmigrasi dimana warganya berasal dari Pulau Jawa, Sumatera, Bali, Sulawesi, NTT, ambon dan NTB.

Pemerintah pusat maupun daerah cukup melakukan pembinaan kebangsaan seperti halnya dalam skala nasional karena adalah hal yang biasa dalam sebuah kehidupan sosial, adanya dinamika sosial seperti konflik baik yang disebabkan oleh persoalan sosial, politik, ekonomi dan lain sebagainya. Beberapa konflik sosial yang pernah terjadi di wilayah Kalteng sejauh ini telah memberikan pelajaran berharga tentang pentingnya pembinaan dalam kehidupan yang majemuk, dimana masyarakat umumnya sudah sadar bahwa berbagai persoalan sosial dan ekonomi hendaknya dapat diselesaikan melalui komunikasi yang baik, serta mencegah lahirnya prasangka negatif terhadap kelompok- kelompok sosial lain.

Penulis berpandangan bahwa di masa yang akan datang, masyarakat Kalteng sudah memahami berbagai persoalan pokok yang kerapkali menjadi pemicu konflik di masyarakat seprti persoalan ekonomi, politik dan provokasi SARA yang seringkali dimainkan oleh elit politik dalam setiap kontestasi dan suksesi pemilihan kepala daerah. Masyarakat adat Kalteng hidup dalam sebuah entitas yang egaliter dan memiliki mekanisme sosial dalam penyelesaian sebuah konflik sosial, sehingga hendaknya dapat dipatuhi oleh semua kalangan agar kehidupan yang harmonis dapat tercipta. Selain itu, penegakan hukum yang berkeadilan serta kebijakan pemerintah yang berpihak kepada masyarakat luas tanpa pandang asal usul dan kepentingan akan meningkatkan kepercayaan publik kepada pemerintah. Ini menjadi dasar utama agar masyarakat tidak lagi menggunakan caranya sendiri dalam penyelesaian konflik dengan pihak-pihak lain di luar kelompok dan etnisnya. 
Kehidupan sosial di Kalteng yang damai dan harmonis pasca konflik yang pernah terjadi diyakini akan tetap dapat dipertahankan mengingat semakin baik dan adilnya proses penegakan hukum di masyarakat. Penulis menganggap bahwa keadilan dalam penegakan hukum akhir-akhir ini telah membentuk masyarakat Kalteng yang sadar dan taat hukum karena kepercayaan yang semakin baik kepada aparat keamanan dalam penyelesaian sengketa maupun konflik yang ada di masyarakat.

Dinamika sosial dan budaya serta potensi terjadinya gejolak akibat perubahan sosial jika Kalteng menjadi ibu kota negara telah dipaparkan oleh gubernur Kalteng dalam beberapa kesempatan. Sebagai bagian dari wilayah Indonesia, Kalteng siap atau tidak mesti menyiapkan diri dalam menjalani status baru sebagai ibu kota negara jika wacana pemindahan tersebut betulbetul direalisasikan.

Beberapa catatan kepada pemerintah pusat adalah pentingnya pelibatan seluruh unsur masyarakat dan adat dalam pembangunan di wilayah Kalteng. Bahkan gubernur Kalteng memaparkan bahwa seluruh tanah masyarakat adat di wilayah Kalteng agar segera disertifikasi untuk mencegah munculnya potensi konflik agraria. Hal ini menandakan bahwa kajian-kajian yang dilakukan tidak boleh tergesa-gesa, karena ada banyak dampak serius yang mesti dihadapi oleh masyarakat manakala sebuah wilayah mengalami perubahan yang besar, dimana ada banyak dimensi yang ikut terpengaruh baik berpengaruh secara negatif ataupun positif.

\section{Aspek Keamanan}

Sebagai sebuah wilayah yang masih relatif kecil, persoalan Kantibmas di wilayah Kalteng relatif masih aman dan belum sebesar persoalan-persoalan kriminal di wilayah perkotaan besar seperti halnya di Jakarta. Namun kecilnya intensitas tindakan kriminal dan kejahatan lainnya akan berubah dinamikanya seiring perubahan status sebagai Kota kecil menjadi wilayah ibu kota negara. 
Karena itu penataan konstruktif terhadap tata ruang calon wilayah ibu kota baru penting untuk diperhatikan. Persoalan kesemerawutan di wilayah Jakarta sebagai ibu kota negara tidak mudah diselesaikan manakala banyak ekses sosial yang akan timbul jika aspek penegakan peraturan daerah tetap dilaksanakan. Hal ini mengganggu ruang publik dan mengurangi kelayakan sebuah wilayah menjadi ibu kota negara baik dari aspek sosial maupun lingkungan hidup.

Berbagai potensi tindakan kriminal dan pelanggaran hukum oleh berbagai kelompok masyarakat dapat diantisipasi dengan upaya pembinaan dan menanamkan simpul-simpul keteraturan sosial yang telah hidup dan berkembang dalam masyarakat Kalteng. Pemerintah dan aparat keamanan hendaknya dapat bekerjasama dengan masyarakat lokal dalam merumuskan prinsip-prinsip kehidupan sosial yang taat hukum dan menghargai pranata adat yang ada untuk mencegah hadirnya kelompok-kelompok di dalam masyarakat yang berpotensi mengganggu keamanan dan ketentrataman hidup bermasyarakat di wilayah Kalteng.

Penulis mendapati adanya keinginan masyarakat agar setiap organisasi sosial kemasyarakatan dapat dibina dan diawasi kegiatannya oleh aparat keamanan dengan tujuan agar tidak ada penyimpangan dalam kegiatannya seperti melakukan tindak kekerasan dan intimidasi terhadap kelompokkelompok Ormas yang lain.

Selain persoalan kriminalitas, pemerintah dapat belajar dari banyaknya konflik yang diakibatkan oleh benturan Ormas-Ormas yang seringkali dibekingi oleh kepentingan para politisi, penguasa, maupun pengusaha. Demi terciptanya kemanan dan ketertiban masyarakat pemerintah tidak boleh ragu untuk meninjau kembali berbagai kebijakan tentang kehidupan berbagai organisasi masyarakat agar kegiatan-kegiatan yang dilakukannya tidak keluar dari garis dan visi-misi organisasi yang seharunya mendukung pemerintah dalam banyak sisi kehidupan bermasyarakat berbangsa dan bernegara. 
Jika kriminalitas terjadi akibat persoalan ekonomi dan sulitnya akses masyarakat atas pekerjaan dan kehidupan yang layak, persoalan Kamtibmas ini justru banyak yang dilakukan atas kepentingan-kepentingan elit politik. Ini menjadi tantangan bagi pemerintah sebelum melakukan perencanaan dan penataan wilayah baru untuk menjadi ibu kota negara.

Penulis berpandangan bahwa ada banyak aspek yang perlu untuk diperbaiki demi terciptanya sebuah situasi sosial yang baik. Selain membangun pusat-pusat ekonomi, industri dan kegiatan ekonomi rakyat, juga keberpihakan terhadap pranta sosial dan lingkungan masyarakat agar tidak ada agi kelompokkelompok masyarakat yang terpinggirkan dan menjadi kelompok marginal di wilayah ibu kota. Kehadiran pusat-pusat bisnis besar dan kurangnya analisis sosial ekonomi di masyarakat menjadikan kegiatan ekonomi masyarakat lokal menjadi mati dan tidak dapat bersaing. Ini merupakan pangkal utama dari instabilitas sosial ekonomi yang memicu terjadinya perbuatan-perbuatan melanggar hukum (kriminal).

Penulis memandang baik adanya pernyataan-pernyataan dari gubernur Kalteng yang tampaknya telah membaca banyak ekses dari pemindahan ibu kota negara di wilayah Kalteng jika memang terwujud. Langkah antisipatif memang penting untuk menciptakan sebuah keteraturan sosial di wilayah Kalteng jika menjadi ibu Kota negara. Penulis menyimpulkan bahwa keamanan dan kondusifitas sebuah wilayah akan terwujud jika seluruh aspek kehidupan masyarakat dapat tersleenggara dengan baik dan adil. Jangan sampai pemindahan ibu kota negara justru menambah persoalan baru bagi wilayah Kalteng.

Jika pranata sosial tetap hidup dan dihargai oleh seluruh warga, dan pemerintah mendukung melalui program-program kebijakan maka berbagai kekhawatiran masyarakat tentang ekses negatif dari pemindahan wilayah ibu kota negara dapat diminimalisir. Dengan demikinan kesejahteraan masyarakat 
dapat terwujud, serta gejolak sosial yang memiliki kaitan langsung terhadap keamanan dan ketentraman masyarakat dapat diminimalisir.

\section{Daya Dukung Lingkungan Hidup}

Wilayah provinsi Kalteng merupakan rumah bagi hutan tropis di Indonesia, dimana hampir 60\% dari wilayah Kalteng masih merupakan kawasan hutan. Ini tampak baik dan cukup mendukung sebuah wilayah ibu kota dimana daya dukung lingkungan hidup merupakan persoalan penting yang perlu untuk dipertimbangkan. Penulis menganggap bahwa salah satu pertimbangan dijadikannya Kalteng sebagai salah satu alternatif dari wilayah ibu kota baru adalah pertimbangan daya dukung lingkungan hidup di Jakarta yang semakin rendah. Selain persoalan sosial yang menyebabkan kesemerautan, juga seringnya bencana banjir yang mengancam wilayah Jakarta setiap musim penghujan datang.

Meskipun wilayah Kalteng khususnya Kota Palangkaraya akhir-akhir ini kerapkali dilanda bajir, beberapa informan mengungkapkan bahwa persoalan banjir di wilayah yang daya dukung lingkungannya masih baik, tidak akan separah di wilayah yang daya dukung lingkungan hidupnya rendah. Mereka mencontohkan bahwa beberapa kejadian banjir di wilayah Kalteng dapat diatasi dengan lebih cepat karena wilayah serapan air dan sungai yang banyak, selain itu cukup dengan penataan ruang yang lebih baik, persoalan banjir yang lebih disebabkan oleh luapan sungai tidak akan berlangsung lama. Ini merupakan tantangan bagi para perencana wilayah kota untuk menciptakan sebuah model pembangunan wilayah perkotaan yang berorientasi pada kelestarian dan keseimbangan lingkungan hidup.

Namun penulis menganalisis bahwa, banyaknya sungai yang mengalir di wilayah Kalteng juga mensyaratkan sebuah pengelolaan terhadap lingkungan hutan yang baik. Karakteristik dari hutan hujan tropis memerlukan sebuah ekosistem yang seimbang dimana wilayah hutan tidak boleh 
dieksploitasi secara berlebihan dan serampangan. Kurangnya wilayah hutan di wilayah tropis akan mengakibatkan banjir dalam intensitas yang lebih parah jika dibandingkan dengan wilayah-wilayah lain. Berbagai kejadian banjir bandang yang seringkali terjadi merupakan dampak dari gundulnya kawasan yang seharusnya merupakan kawasan hutan hujan tropis yang telah mengalami kerusakan.

Penulis merekomendasikan bahwa perlindungan dan pelestarian kawasan hutan merupakan bagian integral dari perencanaan tata ruang yang mulai dikaji secara serius oleh pemerintah. Struktur tanah Kalimantan yang berbeda dengan Pulau Jawa membutuhkan pakar-pakar tata ruang wilayah yang sungguh-sungguh memahami karakteristik lahan gambut yang terdapat pada wilayah-wilayah yang menjadi calon kawasan ibu kota baru. Kita tentu tidak menginginkan resiko ekologis akan mengganggu jalannya roda pemerintahan dan perekonomian di kawasan calon ibu kota negara. Karena meskipun wilayah Kalteng aman dari gempa bumi dan gunung berapi, namun potensi bencana ekologis sudah cukup mengkhawatirkan akibat kerusakan hutan yang semakin luas dan akibat aktivitas pertambangan dan perkebunan dalam skala besar.

Prinsip daya dukung lingkungan yang dimaksudkan disini adalah berfungsinya seluruh komponen lingkungan hidup yang menciptakan sebuah keseimbangan ekosistem. Para ahli lingkungan hidup dan tata ruang tentu memahami karakteristik dan kriteria sebuah lingkungan yang ideal untuk mendukung kehidupan di sekitarnya. Dan muara dari analisis ini adalah bagaimana terbit kebijakan pengelolaan lingkungan yang bertujuan untuk menjaga aspek-aspek pendukung lingkungan hidup seperti pendirian bangunan, alih fungsi lahan, persoalan penebangan hutan dan lahan serta faktor-faktor lain yang bertaut dengan persoalan tersebut.

Kajian terhadap daya dukung lingkungan perlu melibatkan beberapa pihak baik di tingkat pusat maupun daerah. Kementrian lingkungan hidup, 
dinas lingkungan hidup provinsi maupun kabupaten di Kalteng, LSM dan aktivis lingkungan hidup hingga kelompok-kelompok masyarakat adat yang sudah hidup secara turun temurun di wilayah-wilayah yang akan menjadi bagian dari calon ibu kota negara. Hal ini penting untuk menghindari gejolak sosial di masyarakat akibat luasnya alih fungsi lahan yang dapat mempengaruhi situasi kehidupan sosial, ekologi dan pola pemanfaatan lahan warga.

\section{Kesimpulan dan Saran}

Wacana pemindahan ibu kota negara dari Jakarta ke Kota Palangkaraya memerlukan beberapa atensi pokok seperti aspek sosial budaya, daya dukung lingkungan, aspek keamanan dan sumber daya manusia. Selain itu, berbagai kajian ilmiah dan komprehensif agar tidak menghasilkan keputusan yang gegabah yang berakibat pada stabilitas penyelenggaraan pemerintahan negara jika rencana pemindahan ibu kota negara akhirnya direalisasikan di wilayah Provinsi Kalteng.

Secara umum, pemerintah daerah dan sebagian masyarakat Kalteng menyambut baik wacana pemindahan ibu kota negara dari Jakarta ke Kota Palangkaraya, namun masyarakat Kalteng mensyaratkan beberapa hal, termasuk bagaimana agar pemerintah pusat dapat mengakomodir masyarakat Kalteng dalam penyelenggaraan pemerintahan, pengembangan SDM, antisipasi konflik agrarian dan aspek sosial budaya. Hal tersebut sesuai dengan pemaparan gubernur Kalteng bahwa keputusan dari wacana tersebut merupakan wewenang dari pemerintah pusat dan pemerintah daerah Kalteng siap untuk mendukung rencana tersebut. 


\section{Referensi}

Hasibuan, Malayu.2003. Manajemen Sumber Daya Manusia. Jakarta: Bumi Aksara

Kostof, Spiro.1991. The City Shaped: Urban Patterns and Meanings Through History. London: Thames and Hudson

Sonny Harry B Harmadi (2018/10/1-Tribunnews.com

Sumarsono, Sony. 2003. Ekonomi Manajemen Sumber daya Manusia dan

Ketenagakerjaan. Yogyakarta: Graha Ilmu

UU RI No 4 Tahun 1992

UU No. 26 Tahun 2007 Tentang Penantaan Ruang

Kepmen-Kimpraswil No. 327/KPTS/2002 Tentang Penetapan Enam Pedoman dalam Melakukan Penataan Ruang 